\title{
A Lesson Model for Enhancing Motivation in EFL Writing Classes
}

\author{
Selma Deneme \\ Department of Foreign Languages, ELT Division, Trakya University, Turkey \\ Email: selmadeneme@trakya.edu.tr
}

\begin{abstract}
Not many students relish writing; instead, they fear it and avoid it. A lack of motivation is the prime reason behind their predicament. Teachers can positively encourage and motivate their students to write by employing the most appropriate teaching techniques and materials in the classroom. This study aims to propose a lesson model for enhancing motivation in EFL writing classes. The suggested lesson plan was experimentally employed wherein the students were observed and interviewed during and after the class. For data collection of the study, we also utilized a combination of classroom observations and product analysis. The collected data when analyzed and interpreted in the findings of the study indicated that the suggested lesson model was effective in motivating the learners well and encouraging them for writing.
\end{abstract}

Index Terms-increasing motivation, writing in a foreign language, content-based approach, a lesson model

\section{INTRODUCTION}

Motivation, writing and content-based instruction

Research on the psychological aspects of writing commenced a few decades ago, giving away to the motivational reasoning of writing. Encouraging students' positive beliefs about writing, fostering authentic goals as well as contexts for writing and creating a positive classroom environment are some elements that affect students' motivation to write (Bruning and Horn, 2000). According to Jones (1988) "an important challenge for the ESL/EFL writing teacher is to interest and challenge students enough with the course curriculum for them to want to learn to write well" (p. 340). Assigning students appropriate writing topics increases learner motivation and leads to an exciting writing classroom experience (Irmscher, 1979).

One way of increasing students' motivation in writing classes is to employ a content-based instruction methodology. It has been previously used in a variety of language learning contexts for the last few decades. Content-based instruction implies an integration of language learning and content learning while the language is learned within the context of a specific academic subject. In a content-based approach, language class activities are specific to the subject matter being taught and they stimulate students to learn through the use of the target language (Brinton, Snow\&Wesche, 1989). According to Stryker and Leaver (1997), content-based approaches enhance students' motivation and accelerate their acquisition of language proficiency. The four major principles underlying content-based instruction are: automaticity, meaningful learning, intrinsic motivation and communicative competence (Brown, 2001). Brown (2001) also suggests "content-based classrooms may yield an increase in intrinsic motivation and empowerment, since the students are focused on subject matter that is important to their lives" (p. 49- 50). By generating content instruction and materials, content-based instruction keeps students interested and motivated. Content-based classroom is learner centered (Littlewood, 1981) where students actively engage in the learning process. Content-based instruction introduces students to the discourses of their future professions and motivates them to work with authentic language resources (Swales \& Feak, 1995 in Grabe\& Stoller, 1997).The teaching of writing to non-native speakers of English has matured since 1966. Raimes (1996) discussed this development under four approaches: A form-dominated approach, a process approach, a content-based approach and an English for specific purposes approach. In content-based writing instruction, writing is connected to an academic subject matter and it is considered as a means of teaching the content (Beach\&Bridwell, 1984; Emig, 1977; Fulwiler, 1982). Shih (1986) suggests "It is argued that such instruction develops thinking, researching, and writing skills needed for academic writing tasks and does more realistically than does traditional instruction..." ( p. 1).

\section{METHOD}

This qualitative study aims to propose a lesson model to increase learner motivation in EFL writing classes using the content-based approach. The lesson is prepared to teach writing to a group of intermediate level Turkish students learning English as a foreign language at the Department of Tourism at a university in Turkey. The lesson aims to teach a piece of content in an enjoyable writing class and help students profit most from the applied approach during the lesson. It is thought to serve a good model for teachers who want to increase learner motivation in writing classes. Twenty-three Turkish students, 13 boys and 10 girls took part in the study. All participants, chosen randomly, were 
freshman students enrolled in the department of tourism. Before the conduction of the study, consent from both the teacher and their students and school principals was obtained. The suggested lesson model was conducted in the writing class by the researcher in a regular classroom environment, and included an interview as a data collection instrument on the participants. Classroom observation was the second source of data collection procedures. The collected data were analyzed and necessary recommendations were made in the results of the study.

The suggested lesson model was designed to teach writing to the learners of English as a foreign language with content-based instruction. The lesson model was designed taking several points and features of content-based instruction into account. A “six-T's Approach" to unit design by Stoller and Grabe (1997) constituted a basis for the suggested model. The theme selected is of interest to the students enrolled in the department of tourism (a summer holiday resort- the Maldives) while the activities developed meet the needs of the students (replying to e-mail messages, the role of a tourist guide and writing a tour program to the Maldives). It includes the pre, while and post writing stages, and utilized authentic resources in the target language (e.g., an informative power-point slide show). The tasks are communicative in nature (e.g., replying to an e-mail, a role-play) and activities are based on cooperative learning (e.g., learning in pairs, in groups). Students develop the four language skills (power-point slide for listening and reading; replying to an e-mail develops writing; role-play develops listening and speaking skills). Three experts in the field were consulted for the validity, the reliability and the practicality of the suggested model. Their opinions about the suggested model in terms of form and content were obtained. All of the experts agreed that the model was appropriate both in form and in content.

\section{SUGGESTED LESSON MODEL}

The suggested model was presented under two sub-headings: lesson plan and classroom applications. The level of the students, the subject and the duration of the course, the course objectives were given and the three stages of the writing lesson (pre-writing, while writing and post-writing) were described in detail in the lesson plan. In the classroom applications part, the teaching steps were described in detail.

\section{A. Lesson Plan}

Replying to e-mail messages

Students: Freshman students (enrolled in the Department of Tourism) learning English as a foreign language

Course: English

Level: Intermediate

Subject: A glimpse of the Maldives

Duration: $45+45$ minutes

Approach: Content-based Instruction

Materials: Teacher-created slides: a visual resource for clarifying content and developing writing skills

Lesson Objectives:

-learning about the Maldives

-picking up necessary language from the slides

-responding to a customer e-mail giving detailed information about the Maldives

Pre-writing stage:

Classroom Discussion: The students talk about their favourite holiday resorts.

Introducing relevant vocabulary and idioms before writing

Note Taking: Students take notes during the slide show (22 teacher produced slides).

\section{While writing stage:}

The students are asked to write an e-mail replying to a customer who is asking for advice about a nice summer holiday resort for his summer vacation. They will write a detailed e-mail about the Maldives by introducing the resort to the customer. They will write in groups of 3 students (Group work). For the task, the students use their notes taken from the slide show.

\section{Post- writing stage:}

The students were placed in pairs and assigned to play the roles of a tourist and a tourist guide.

Student A: A tourist in the Maldives wants to learn about it as much as possible, asks whatever he wants to learn from the tourist guide.

Student B: A tourist guide, answers the guest's questions as much as he can.

Peer editing and giving feedback

Rewarding the best writer

\section{Homework:}

The students write a package tour program to the Maldives individually.

Instruction: You are a tour operator and required to write a package tour programme to the Maldives in detail (250300 words). Write about tour dates, the cost of the tour, transportation and accomodation, the planned daily activities on the island, and etc.

\section{B. Classroom Applications}


The researcher herself conducted the lesson. First, she held a warm up session, motivating the students and focussing their attention to the topic. Later, she conducted the pre-writing stage consisting of a class discussion activity, during which the students discussed their favourite holiday resorts. After the class discussion, the informative slides about the Maldives were presented and the students took notes from the slides in order to use them in their writing. Finally, they were asked to do the writing task (writing a reply to an e-mail). The students were given ample time to write the task. They did the task in groups of three students. Having completed the task, they read it aloud and received feedback from the researcher and from the whole class. After the task was over, a role-play activity was conducted by pairs of students as a post-writing activity playing the role of a tourist and a tourist guide. With the post-writing activity, writing was integrated with speaking and the subject matter was reinforced. The students were assigned homework at the end of the class.

\section{RESULTS AND DISCUSSION}

According to Gardner (1985), three components are necessary for motivation language learning: effort to achieve a goal, desire to learn the language and satisfaction with the task of learning the language. Characteristics such as effort, persistence, and attention are the descriptors of the motivational behaviour and such characteristics of an individual can be perceived by an outside observer (Tremblay\& Gardner, 1995).

The researcher, as an observer, assessed the students' motivational behaviour in the classroom. The students were found to be persistent; they attended to the task for a long period of time, signalling high learner motivation (Maehr $\&$ Braskamp, 1986). In addition, they directed attentional effort to the writing task. As there is a close link between motivation and attention (Crookes \& Schmidt, 1991), the students were considered highly motivated during the lesson. They spent considerable energy on taking notes, participating in pairs and group works, and writing dialogues, giving additional signs of motivation.

The students seemed to enjoy the lesson and participated successfully by taking notes, writing the task and interacting with one another. They did not show any signs of boredom during the lesson. On the contrary, they were very much interested in the topic and undertook the task successfully. They seemed to enjoy the group-work and pairwork activities. They also showed positive attitudes in working with class-mates.

Their written products also confirmed that they were motivated and performed well during the lesson. When the written products were evaluated, they were found to be complete in form and meaning. Composed of syntactically and semantically appropriate sentences, the written products included the necessary vocabulary items to describe the intended facts and opinions. Furthermore, the written products were found to be cohesive, coherent and relevant with all ideas supporting one central theme using suitable linking devices. The written texts were also successful in terms of function; the e-mails written to a customer to persuade him to buy a package tour to Maldives were extremely effective and persuasive as the students wrote about all the attractions in the islands.

The students were interviewed following the lesson and their opinions about the lesson were recorded and subsequently investigated. The question "What do you think about the writing lesson you were taught?" was directed to all of them and the replies were as follows: (mechanical errors corrected and identical responses written once only)

-I noticed I like writing for the first time.

-I liked the lesson, it was enjoyable.

-It was not boring as regular writing classes, I enjoyed it.

-I liked the slides, they really helped me with my writing. I used the ideas and the vocabulary presented in the slides.

-I find it very beneficial, it is related to my field. I like learning English related to my field.

-It was fun, I wanted to write.

-I usually waste a lot of time before I start to write as I usually do not know what to write and how to start. But this lesson was different; it taught ideas and the words before writing.

-I liked the topic "The Maldives", I wanted to write about it although I don't like writing.

-I liked to write and speak in English while learning about a touristic place. Previously, I did not know much about this island.

-I think we should always learn English related to our field, I will need to use English in the field of tourism in the future.

-It was easier and more comfortable to write with my friends.

-The lesson was so interesting for me. I learnt a bit more about the real world.

-I liked the slide show, it really helped me with my writing. I used the ideas and the vocabulary presented in the slides.

-It was even easier to play the roles of a tourist and a tourist guide after learning the necessary vocabulary.

-I never like writing but I wrote an e-mail and participated in the activities.

The students' responses to the interview showed that they enjoyed the lesson and the topic. The students liked the topic as it was authentic and related to their field. The answers reveal that they had no difficulty in generating ideas and using the required vocabulary as they were previously introduced to them in the slides. They considered the lesson beneficial as it was related to their fields of study. They indicated their desire to learn language related to their fields. The results of the study support previous research in that important and interesting content provides motivation to learn 
(Irmscher, 1979; Stryker\&Leaver, 1997; Brown, 2001). They find writing with their friends easier and more comfortable. Their responses correspond with research on cooperative learning. When students work in groups, there is improvement in students' learning (Slavin, 1995). The answers indicate that they all did the task willingly. They also reported to have enjoyed the integration of speaking as a post-writing activity.

The model worked well in the class in encouraging writing. Based on the result of the study, the lesson model is suggested to be adapted and used by teachers in writing classes to motivate and encourage students to write. This study is limited to the teaching of writing and to a small number of participants. Thus, it is suggested that further studies be conducted with larger numbers of participants for proposing new models of teaching other language skills. With regard to data collection in future studies, additional methods may be applied with a larger number of participants, such as detailed product analysis, and using motivation scales.

\section{REFERENCES}

[1] Beach, R., and Bridwell, L. (1984). Learning through writing: A rationale for writing across the curriculum. In A.D. Pellegini \& T.D. Yawkey (Eds.), The development of oral and written language in social contexts (pp. 183-198). Norwood, NJ: Ablex.

[2] Brinton,D., Snow, M. A., Wesche, M. B.(1989). Content-based second language instruction. Rowley, MA: Newbury House.

[3] Brown, H. D. (2001). Teaching by principles: an interactive approach to language pedagogy Second Edition. NY: Pearson Education.

[4] Bruning, R. , and Horn, C. (2000). Developing motivation to write. Educational Psychologist, 35, 25 - 37.

[5] Crookes, G., and Schmidt, R.W.(1991). Motivation: Re-opening the research agenda. Language Learning, 41, 469- 512

[6] Emig, J. (1977). Writing as a mode of learning. College Composition and Communication, 28, 122- 128.

[7] Fulwiler, T. (1982). Writing: An act of cognition. In C.W. Griffin (Ed.), Teaching writing in all disciplines (pp. 15- 26). San Francisco: Jossey- Bass

[8] Gardner, R. C. (1985). Social psychology and second language learning: The roles of attitudes and motivation. London: Edward Arnold.

[9] Grabe, W., and Stoller, F.L. (1997). Content-based instruction: research foundations. In M.A. Snow and D. M Brinton (Eds.), The content-based classroom: Perspectives on integrating language and content (pp. 5- 21) NY: Longman.

[10] Stoller, F.L. and Grabe, W. (1997). A six-T's approach to content-based instruction. In M. A. Snow \& D. M. Brinton (Eds.), The content-based classroom: Perspectives on integrating language and content (pp. 78-94). NY: Longman.

[11] Irmscher, W.F. (1979). Teaching expository writing. New York: Holt, Rinehart \& Winston.

[12] Jones, N. B. (1998). Comments on Tony Silva's "On the ethical treatment of ESL writers": a defense of using themes and topics to teach ESL/EFL writing. TESOL Quarterly, 32 (2). 338- 342.

[13] Littlewood, W. (1981). Communicative Language Teaching. New York: Cambridge University Press.

[14] Maehr, M.L., and Braskamp, L. A. (1986). The motivation factor. A theory of personal investment. Lexington, MA: Lexington Books.

[15] Raimes, A. (1991). Out of the Woods: emerging traditions in the teaching of writing, TESOL Quarterly, 25 (3). $407-430$.

[16] Shih, M. (1986). Content-based approaches to teaching academic writing. TESOL Quarterly, 20 (4), $617-648$.

[17] Slavin, R. E. (1995). Cooperative learning: Theory, research, and practice (2nd ed.). Boston: Allyn \& Bacon.

[18] Stoller, F.L., and Grabe, W. (1997). A six-T's approach to content-based instruction. In M. A. Snow \& D. M. Brinton (Eds.), The content-based classroom: Perspectives on integrating language and content (pp. 78- 94). NY: Longman.

[19] Stryker, S.B. and Leaver, B.L. (1997). Content-based instruction in foreign language education: models and methods. Washington, D.C: Georgetown University Press.

[20] Tremblay, Paul. F., and Gardner, R. C. (1995). Expanding the motivation construct in language learning. The Modern Language Journal. 79 (4), 505- 518.

Selma Deneme was born in Ankara in 1969. She graduated from Gazi University in 1996 (as honour student) and she earned her MA in 2000, in the field of ELT from Gazi University- Turkey, and her PhD from Ankara University- Turkey in the field of FLT in 2008.

She has been teaching more than 15 years- worked at Gazi University as an instructor for 13 years, and as an assistant professor at Trakya University from 2009 up to present. She has publications in the field: 2008, "Language Learning Strategy Preferences of Turkish Students", Journal of Language and Linguistic Studies; 2010, "Teaching English as a Foreign Language to Very Young Learners: A Case from Turkey", Language in India; 2010," Cross cultural differences in language learning strategy preferences: A comparative study", The International Journal of Language, society and culture, She is mostly interested in ELT methodology, language learning strategies, academic writing, teaching English to young learners and teacher training, At present, she is an assistant professor at Trakya University- ELT Division.

Dr. Deneme has received two best paper awards from pedagogy and the knowledge society- Croatia- the first one was for her paper "An Application of skills Integration in Language Teaching" in 2009 and the second was for "Trakya Children's University: The English compartment" in 2010. 